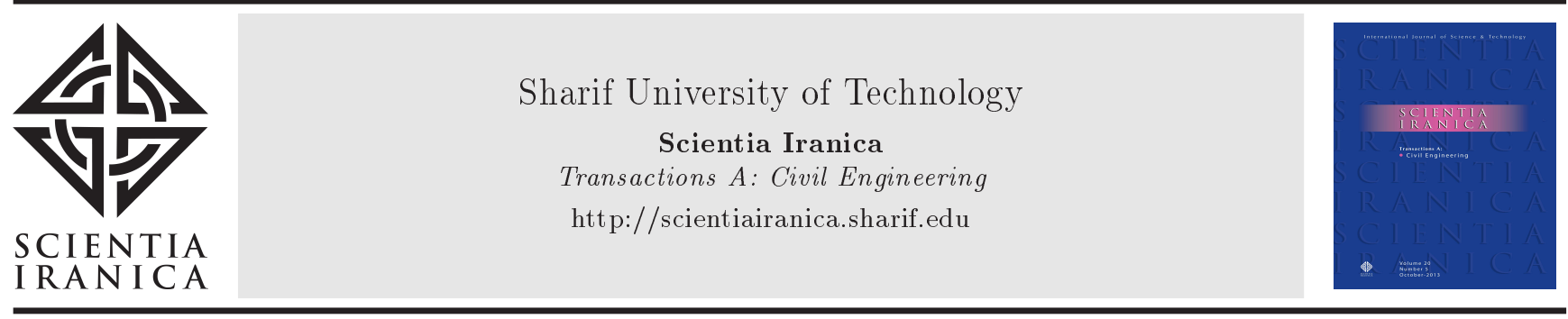

Research Note

\title{
Numerical modeling of a new reinforced masonry system subjected to in-plane cyclic loading
}

\author{
B. Shakarami, M.Z. Kabir*, and R. Sistani Nezhad \\ Department of Civil and Environmental Engineering, Amirkabir University of Technology, Tehran, Iran.
}

Received 15 October 2017; received in revised form 10 October 2018; accepted 25 December 2018

\section{KEYWORDS}

Reinforced Masonry

(RM);

Un-Reinforced

Masonry (URM);

Ductility;

Energy absorption;

In-plane cyclic

loading.

\begin{abstract}
This paper describes the behavior of walls under in-plane cyclic shear compression of a new reinforced masonry system composed of horizontal and vertical reinforcements based on Iran's national building regulation codes in two groups. In the first group, grid-type steel bars were mounted on the cement core between solid clay bricks (double-wythe); in the second group, common grid-type steel bars were mounted on perforated bricks and trusses as horizontal reinforcements using advanced numerical simulation (LS-DYNA). A nonlinear finite element discrete modeling according to stressstrain models was applied to represent the previously modeled masonry walls. Masonry units included perforated bricks and solid clay bricks, and the mortar and bonding interfaces were shown as continuum elements. In order to validate the micro-modeling strategy, the input data were based on a reinforced masonry wall previously tested in the laboratory with clear identification and justification. Accordingly, the main objective of this paper is to (a) examine results of specimens in terms of maximum strength, ductility, energy absorption, and failure modes, (b) investigate the effect of aspect ratio and reinforcement type, and (c) compare the modeled walls with other reinforced systems.
\end{abstract}

(C) 2020 Sharif University of Technology. All rights reserved.

\section{Introduction}

Masonry structures are highly sensitive to lateral loads induced by earthquakes. Some techniques can be used during the construction of masonry structures to enhance masonry response and some methods can be used for existing buildings as strengthening techniques [13]. Over the past years, many scientists worked in masonry fields and proposed different techniques of confining and reinforcing masonry elements. There

*. Corresponding author. Tel.: 0216400243 ;

Fax: 021 6414213

E-mail addresses: bshakarami@aut.ac.ir (B. Shakarami);

mzkabir@aut.ac.ir (M.Z.Kabir);

razieh.sistaninejad@aut.ac.ir (R. Sistani Nezhad)

doi: $10.24200 /$ sci.2019.5376.1237 are several reasons why scientists have provided a wide range of strengthening techniques and design approaches in masonry structures. However, increased vulnerability and carrying capacity might be among important factors that persuade scientists to suggest different approaches [4]. This issue explains the need for progressive large-scale seismic strengthening with techniques accessible to ordinary construction. These techniques certainly have various advantages and disadvantages, which play a consequential role in the performance of masonry structures.

Although the advantages of reinforced masonry outweigh the disadvantages, it is necessarily necessary to evaluate some merits and demerits of reinforced masonry walls to appreciate the behaviors and performances in detail $[5,6]$. Fiber Reinforced Polymer (FRP), grid-type steel bars, confined ele- 
ments, strut, and tie model are the most popular sources of strengthening; however, due to the paucity of guidance, design assessment, effective detailing rules, and so forth, scientists may confront a challenging problem despite some accurate and reliable outcomes from different tested walls by Shermi and Dubey [7], Dehghani et al. [8], and Mohebbi and Joghataie [9]. A typical case of masonry reinforcement is the application of steel bars to hollow perforated units. The role of steel bars in creating continuity between masonry units is highly observable [10,11]. Hollow masonry units partially and fully grouted with mortar are among the techniques used for masonry construction [12,13]. Da Porto et al. investigated the effectiveness of this technique in the in-plane resistance of masonry panels $[14,15]$. They attempted to evaluate a new technique regarding steel meshes of grid type through numerical modeling. This solution includes the development of the in-plane behavior of masonry walls.

In Iran, the same construction method with perforated units and vertical reinforcements has frequently been used in recent years. Moreover, the key factor of masonry construction is to resist earthquake loads, which are likely to be transferred based on the direction of loads $[1,16]$. Therefore, performing the numerical and experimental study of the in-plane behavior of masonry construction is of significance when it comes to the reinforced masonry system. Micro and macro modeling approaches are of utmost importance to numerical analysis, which has been used extensively over the years. In the macro-modeling approach, there is no difference between brick units and mortar, and a homogenization approach is used to obtain the mechanical characteristics of new materials. However, in the micro modeling method, more precisely, both brick units and mortar joints are taken separately into consideration and an interface element is taken to model the discontinuity of masonry constituents. Potential cracks, failure modes, and so forth are the main advantages of the micro modeling approach. However, still, masonry construction needs a welldeveloped micro model $[17,18]$.

This paper offers two groups of a newly reinforced masonry wall: grid-type steel bars mounted on the cement among solid clay bricks (doable-wythe walls). Due to a paucity of information on experimental programs and their effectiveness, the main aim of analyzing this type is to assess their behavior in comparison to perforated brick walls. To this end, the Developing Innovative System (DIS) wall project which plays a significant role in the investigation of clay units and steel bars is utilized and a new method is proposed accordingly [19]. Thus, the general and basic characteristics of the materials and masonry construction have widely been clarified [20].

\section{Reinforced masonry system}

Grid-type reinforcement including horizontal and vertical steel bars explicates this new system. Particular characteristics of clay masonry units could provide thorough verification (see Figure 1). Indeed, holes in perforated bricks allow vertical steel bars to be located in the units. In terms of mechanical behavior, this system makes a significant contribution to the stability and durability of the wall and prevents fragility of units, mortar, and reinforcement despite transferring horizontal loads.

\section{Verification}

Firstly, to investigate and compare the behaviors of Reinforced Masonry (RM) and Un-Reinforced Masonry (URM), an experimental model proposed by da Porto et al. [21] was made by Ls-Dyna and then, both numerical and experimental models were compared (see Figure 2). Afterward, the verification of reinforced masonry walls with the experimental model proposed by da Parto et al. [20] and Tomaževiè et al. [22] (TRSb06) was done to gain an analytical comparison between the numerical and experimental models (see Figures 2 and 3 ). In addition, shapes and dimensions of the numerical model are depicted in Figure 4. Hence, the basic properties of the materials (units, mortar, and reinforcement) for the numerical modeling in LS-DYNA are shown in Tables 1-3. Also, Lorenco [23] provides properties and parameters for modeling cracks in bricks.

\section{Numerical modeling}

As previously mentioned, the behavior of Un-reinforced

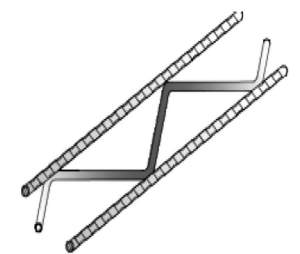

(a)

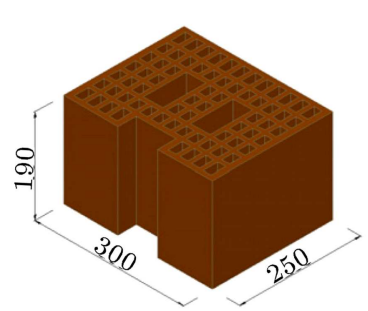

(c)

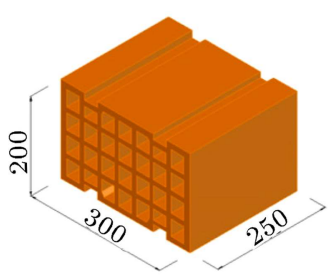

(b)

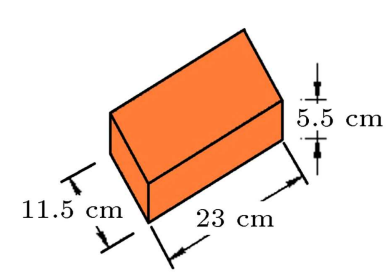

(d)
Figure 1. Details of (a) horizontal truss reinforcement, (b) horizontally perforated unit, (c) vertically perforated unit, and (d) solid unit. 
Table 1. Mechanical properties of double-wythe walls.

\begin{tabular}{cccccccc}
\hline Bricks & \multicolumn{4}{c}{ Joint } & \multicolumn{2}{c}{ Cement part } \\
\hline $\boldsymbol{E}\left(\mathbf{N} / \mathbf{m m}^{\mathbf{2}}\right)$ & $\boldsymbol{\nu}$ & $\boldsymbol{F}_{\boldsymbol{r}}(\mathbf{M P a})$ & $\boldsymbol{k}_{\boldsymbol{n}}\left(\mathbf{N} / \mathbf{m m}^{\mathbf{3}}\right)$ & $\boldsymbol{k}_{\boldsymbol{s}}\left(\mathbf{N} / \mathbf{m m}^{\mathbf{3}}\right)$ & $\boldsymbol{E}\left(\mathbf{N} / \mathbf{m m}^{\mathbf{2}}\right)$ & $\boldsymbol{\nu}$ & $\boldsymbol{F}_{\boldsymbol{c}}^{\prime}\left(\mathbf{k g} / \mathbf{c m}^{\mathbf{2}}\right)$ \\
\hline 15270 & 0.2 & 0.86 & 31.90 & 17.07 & 15572 & 0.2 & 150 \\
\hline
\end{tabular}

Table 2. Elastic properties of the bricks and joints (perforated bricks).

\begin{tabular}{cccccccc}
\hline \multicolumn{3}{c}{ URM $^{\mathbf{a}}$} & & \multicolumn{3}{c}{ RM $^{\mathbf{b}}$} \\
\hline Brick & \multicolumn{2}{c}{ Joint } & Brick & & Joint \\
\hline $\boldsymbol{E}$ & $\boldsymbol{\nu}$ & $\boldsymbol{k}_{\boldsymbol{n}}$ & $\boldsymbol{k}_{\boldsymbol{s}}$ & $\boldsymbol{E}$ & $\boldsymbol{\nu}$ & $\boldsymbol{k}_{\boldsymbol{n}}$ & $\boldsymbol{k}_{\boldsymbol{s}}$ \\
\hline $9269\left(\mathrm{~N} / \mathrm{mm}^{2}\right)$ & 0.22 & $34.90\left(\mathrm{~N} / \mathrm{mm}^{3}\right)$ & $14.42\left(\mathrm{~N} / \mathrm{mm}^{3}\right)$ & $9269\left(\mathrm{~N} / \mathrm{mm}^{2}\right)$ & 0.2 & $35.20\left(\mathrm{~N} / \mathrm{mm}^{3}\right)$ & $16.42\left(\mathrm{~N} / \mathrm{mm}^{3}\right)$ \\
\hline
\end{tabular}

a: URM: Un-Reinforced Masonry. b: RM: Reinforced Masonry.

Table 3. Inelastic properties of the joint.

\begin{tabular}{|c|c|c|c|c|c|c|c|c|c|c|c|c|c|}
\hline \multicolumn{6}{|c|}{$\mathrm{URM}^{\mathrm{a}}$} & & \multicolumn{7}{|c|}{$\mathbf{R M}^{\mathbf{b}}$} \\
\hline \multicolumn{2}{|c|}{ Tension } & \multicolumn{4}{|c|}{ Shear } & \multirow{2}{*}{$\frac{\text { Cap }}{F_{m} C_{s s}}$} & \multicolumn{2}{|c|}{ Tension } & \multicolumn{4}{|c|}{ Shear } & \multirow{2}{*}{$\begin{array}{c}\text { Cap } \\
F_{m} C_{s s}\end{array}$} \\
\hline$F_{t}$ & $G_{f}^{1}$ & $c$ & $\tan \phi$ & $\tan \psi$ & $G_{f}^{2}$ & & $F_{t}$ & $G_{f}^{1}$ & $c$ & $\tan \phi$ & $\tan \psi$ & $G_{f}^{2}$ & \\
\hline $\begin{array}{c}0.36 \\
\left(\mathrm{~N} / \mathrm{mm}^{2}\right.\end{array}$ & $\begin{array}{r}0.026 \\
(\mathrm{~N} / \mathrm{mm}\end{array}$ & $\begin{array}{c}0.05 \\
\left.\mathrm{~N} / \mathrm{mm}^{2}\right)\end{array}$ & 0.40 & 0.0 & $\begin{array}{c}0.44 \\
(\mathrm{~N} / \mathrm{mm})\end{array}$ & $11 \quad 16$ & $\begin{array}{c}0.36 \\
\left(\mathrm{~N} / \mathrm{mm}^{2}\right.\end{array}$ & $\begin{array}{c}0.026 \\
(\mathrm{~N} / \mathrm{mm})\end{array}$ & $\begin{array}{c}0.07 \\
\left(\mathrm{~N} / \mathrm{mm}^{2}\right)\end{array}$ & 0.45 & 0 & $\begin{array}{c}0.44 \\
(\mathrm{~N} / \mathrm{mm})\end{array}$ & $\begin{array}{ll}11 & 16\end{array}$ \\
\hline
\end{tabular}

a: URM: Un-Reinforced Masonry. b: RM: Reinforced Masonry.

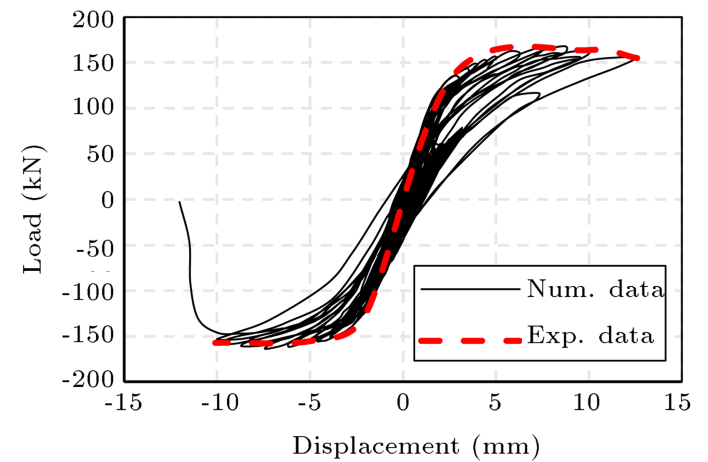

(a)

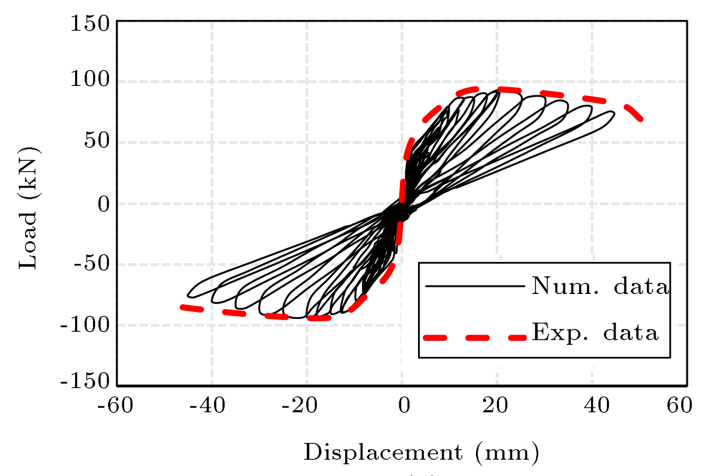

(b)

Figure 2. (a) Comparison of numerical finite element model and experimental Un-Reinforced Masonry (URM) [21] and (b) comparison between experimental and modeled cyclic shear compression tests [20]. Slender specimens tested under $0.6 \mathrm{~N} / \mathrm{mm}^{2}$ vertical compressions.

masonry walls with special clay bricks through numerical finite element modeling (LS-DYNA) was verified based on an experimental model tested previously in the laboratory (see Figure 2). The numerical model of reinforced masonry walls used in this study was validated by da Porto et al. The verification of the reinforced masonry numerical model based on the corresponding experimental tests is depicted in Figures 2 and 3 with a close similarity, a crack pattern, and the presence of a high shear force. In the numerical analysis, in-plane cyclic loading was considered and displacement as horizontal loading was applied at the mid-height of the concrete beam modeled at the top of the wall.

\section{Geometrical properties}

Reinforced Masonry walls with different dimensions and steel bars were considered in the parametrical analysis, as presented in Figure 5. Each specimen is characterized by a three-part name. The first part is devoted to the shape of the walls; SQ, SL, and HR for SQuat, Slender, and Horizontal Rectangle walls, respectively. Reinforced masonry and perforated bricks in the second part are used as reinforced masonry and perforated brick and the numbers refer to the size of steel bars (see Tables 4 and 5).

\section{Finite element mesh}

Continuum and interface elements of LS-DYNA simulation were selected for the creation of mesh elements, and the eight-node plane-stress continuum element based on a Gaussian quadrature scheme was adopted to model each masonry unit [24]. Then, an interface element (6-node) was used at the mid-length of units in order to represent cracks. Also, to check the convergence of the solution, at least two solutions to the same 

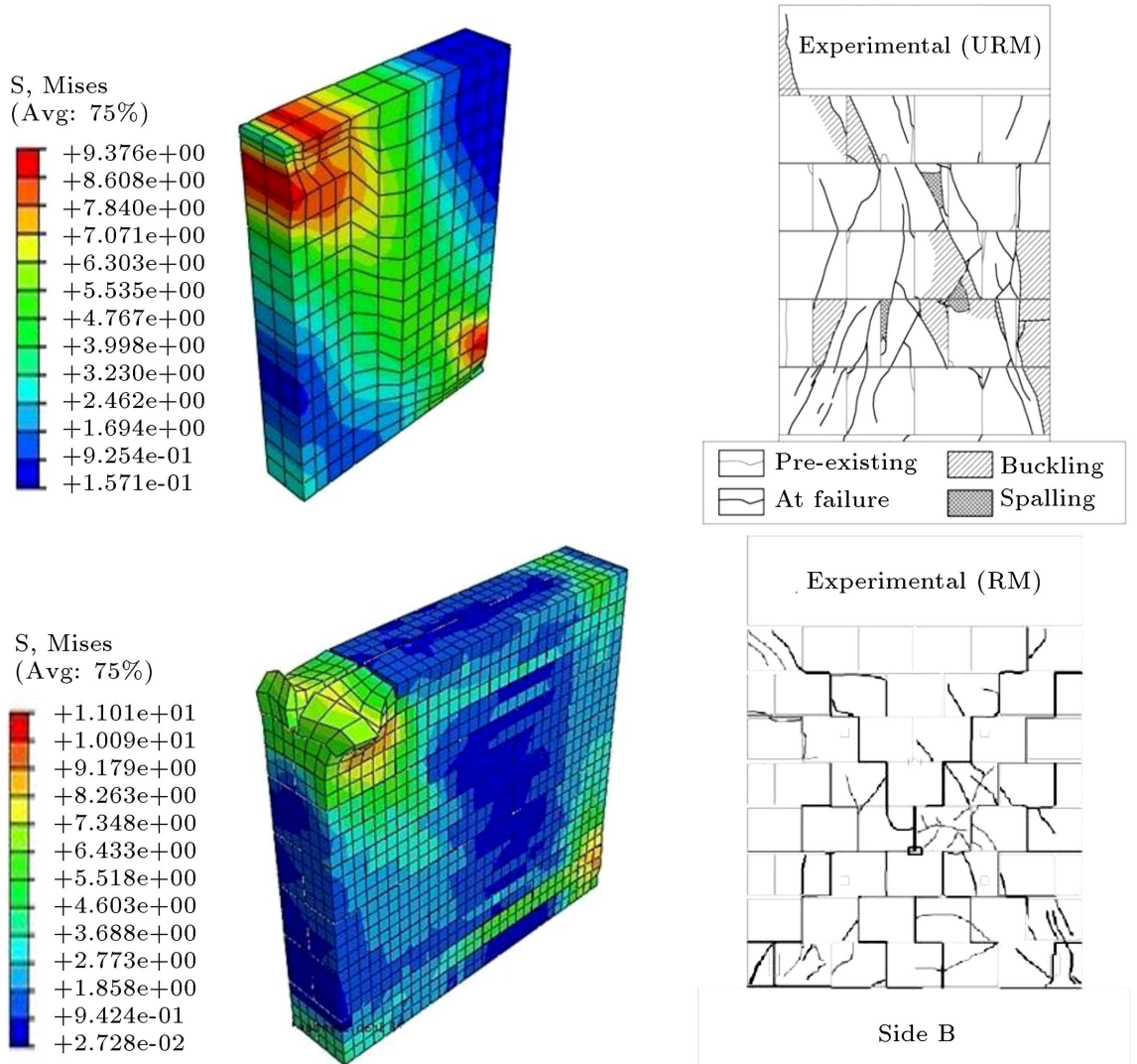

Experimental (RM)

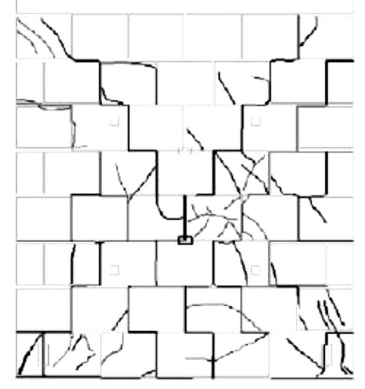

Side B

Figure 3. Crack patterns of Un-Reinforced Masonry (URM) and Reinforced Masonry (RM) walls after shear-compression test. Principal compressive stresses at ultimate load.
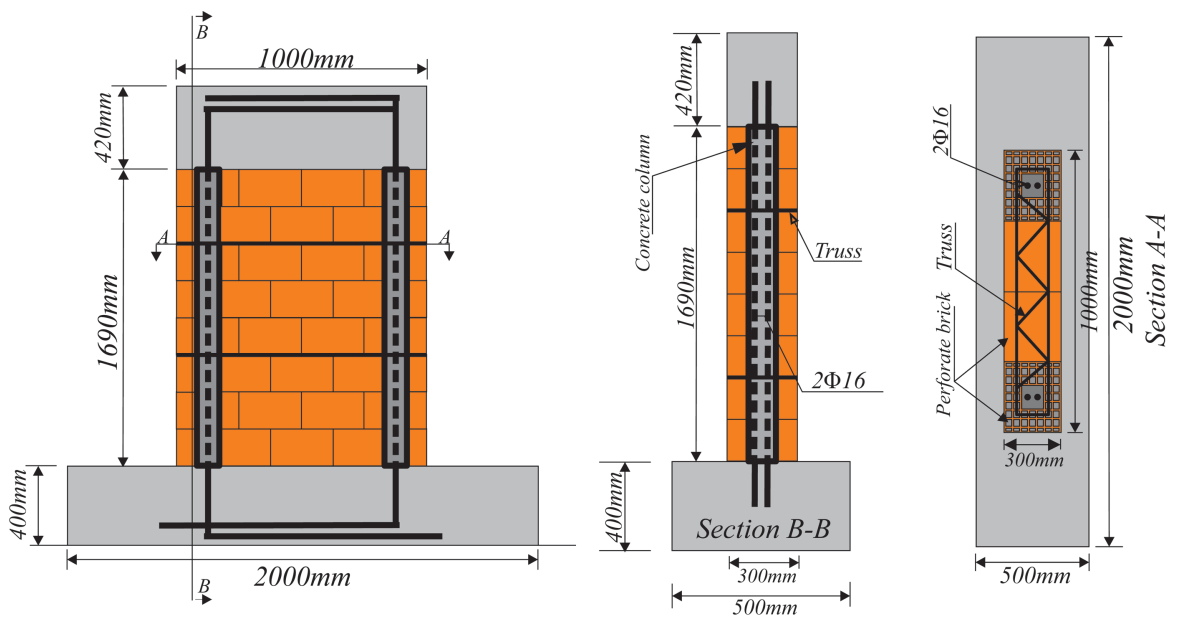

Figure 4. Shape and dimensions of tested reinforced masonry walls and typical distribution of reinforcement.

problem are required. The solution from the finite element program was checked with a highly accurate solution. If this solution is significantly different from the original solution, then it does not reach convergence. However, if this difference between the two solutions is not considerable (less than a few percent difference), then the solution is considered converged. Based on the information provided in Figure 6(a), the size of the element $(10 \mathrm{~mm})$ for creating mesh was selected.

\section{Loading and boundary condition}

In this study, the specimens are subjected to the inplane cyclic loading. The compressive axial load, as gravitational load, was applied at the first step and kept constant. Horizontal displacement was consequently applied to the top of the walls until failure. In the numerical modeling, in-plane cyclic loads were applied to the models with a fixed base and a free direction at 

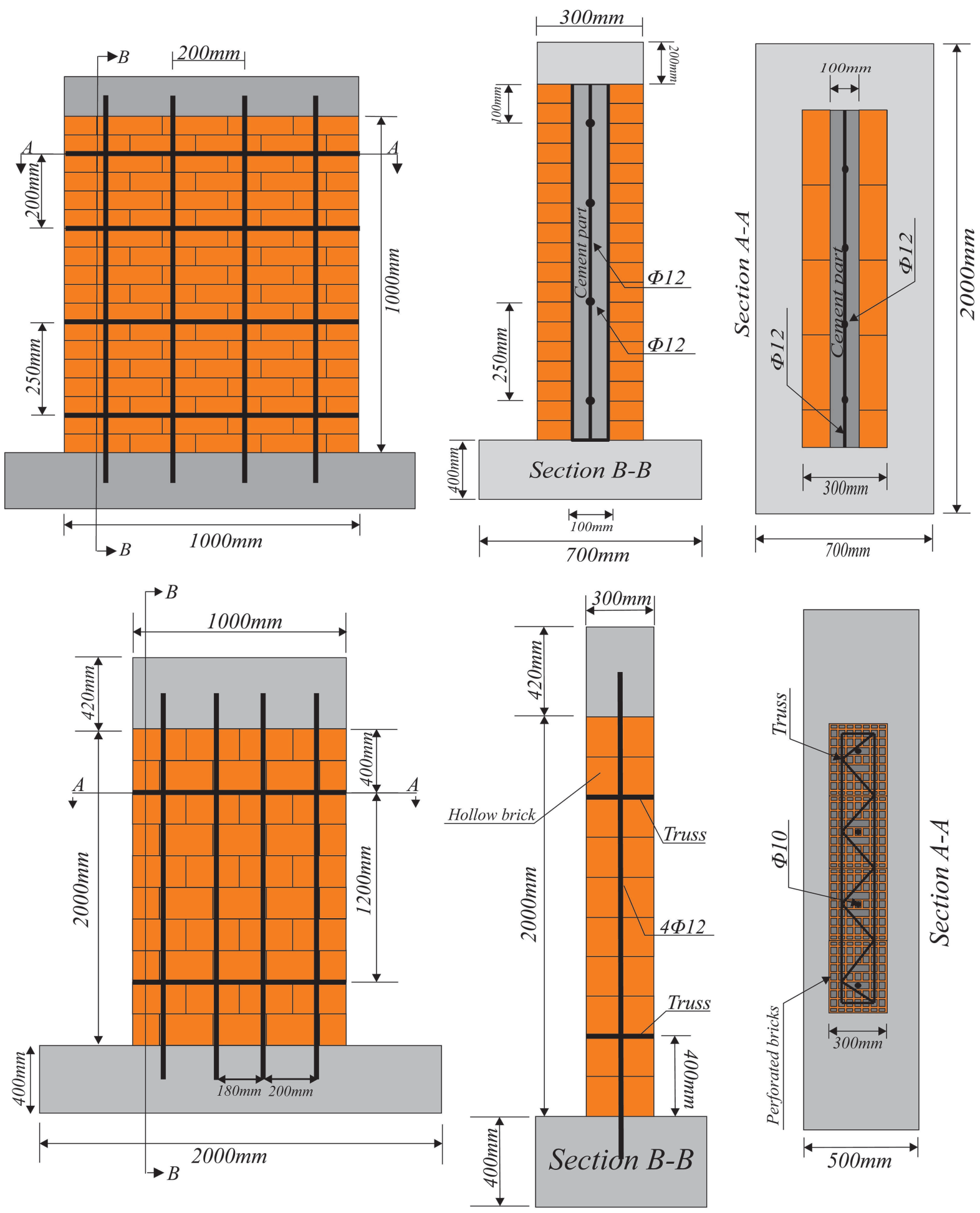

Figure 5. Dimension of double-wythe and perforated brick walls, steel bars mounted on (a) cement core and (b) hollow bricks using $\Phi 10$ and $\Phi 12$ steel bars.

the top of the wall to rotate. Moreover, a compressive axial load as the gravity load was applied and kept constant. Figure 6(b) shows the sequence of horizontal displacements applied to the top of the walls [25]. Regarding the boundary condition when considered as an integral part of a structural masonry building, masonry walls tend to be fixed mostly at top and bottom boundaries, meaning that the restriction is effective at both ends. Continuum elements representing the masonry units located at the base of the wall were connected to the interface elements, which were fully fixed to simulate fixed base conditions for 
Table 4. First group of reinforced masonry walls (double-wythe).

\begin{tabular}{|c|c|c|c|c|c|}
\hline \multirow[t]{2}{*}{ Specimens } & \multirow{2}{*}{$\begin{array}{l}\text { Dimension of } \\
\text { wall }(\mathrm{mm})\end{array}$} & \multirow{2}{*}{$\begin{array}{l}\text { Type of } \\
\text { bricks }\end{array}$} & \multirow{2}{*}{$\begin{array}{c}\text { Dimension of cement } \\
\text { part }(\mathrm{mm})\end{array}$} & \multicolumn{2}{|c|}{ Reinforcement } \\
\hline & & & & Longitudinal & Transverse \\
\hline \multirow[t]{2}{*}{$\mathrm{SQ}^{*} \mathrm{RM} 10$} & $1000 \times 100 \times 1000$ & Clay brick & $1000 \times 100 \times 1000$ & $4 \Phi 10$ & $4 \Phi 10$ \\
\hline & & & & $6 \Phi 10$ & $6 \Phi 10$ \\
\hline \multirow[t]{2}{*}{ SQRM12 } & $1000 \times 100 \times 1000$ & Clay brick & $1000 \times 100 \times 1000$ & $4 \Phi 12$ & $4 \Phi 12$ \\
\hline & & & & $6 \Phi 12$ & $6 \Phi 12$ \\
\hline \multirow[t]{2}{*}{$\mathrm{SL}^{* *} \mathrm{RM} 10$} & $1000 \times 100 \times 2000$ & Clay brick & $1000 \times 100 \times 2000$ & $4 \Phi 10$ & $4 \Phi 10$ \\
\hline & & & & $6 \Phi 10$ & $6 \Phi 10$ \\
\hline \multirow[t]{2}{*}{$\mathrm{SLRM}^{* * *} 12$} & $1000 \times 100 \times 2000$ & Clay brick & $1000 \times 100 \times 2000$ & $4 \Phi 12$ & $4 \Phi 12$ \\
\hline & & & & $6 \Phi 12$ & $6 \Phi 12$ \\
\hline \multirow[t]{2}{*}{ HRRM10 } & $2000 \times 100 \times 1000$ & Clay brick & $2000 \times 100 \times 1000$ & $4 \Phi 10$ & $4 \Phi 10$ \\
\hline & & & & $6 \Phi 10$ & $6 \Phi 10$ \\
\hline \multirow[t]{2}{*}{ HRRM12 } & $2000 \times 100 \times 1000$ & Clay brick & $2000 \times 100 \times 1000$ & $4 \Phi 12$ & $4 \Phi 12$ \\
\hline & & & & $6 \Phi 12$ & $6 \Phi 12$ \\
\hline
\end{tabular}

$* \mathrm{SQ}=\mathrm{SQuat},{ }^{*} \mathrm{SL}=\mathrm{SLender},{ }^{* * *} \mathrm{RM}=$ Reinforced Masonry

Table 5. Second group of reinforced masonry walls (perforated bricks).

\begin{tabular}{|c|c|c|c|c|}
\hline \multirow[t]{2}{*}{ Specimens } & \multirow[t]{2}{*}{ Dimension of wall (mm) } & \multirow[t]{2}{*}{ Type of bricks } & \multicolumn{2}{|c|}{ Reinforcement } \\
\hline & & & Longitudinal & Transverse \\
\hline SQPB10 & $1000 \times 300 \times 1000$ & Perforate brick & $\begin{array}{lll}4 & \Phi & 10 \\
6 & \Phi & 10\end{array}$ & Truss \\
\hline $\mathrm{SQPB}^{*} 12$ & $1000 \times 300 \times 1000$ & Perforate brick & $\begin{array}{l}4 \Phi 12 \\
6 \Phi 12\end{array}$ & Truss \\
\hline SLPB10 & $1000 \times 300 \times 2000$ & Perforate brick & 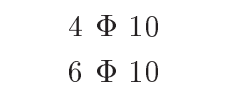 & Truss \\
\hline SLPB12 & $1000 \times 300 \times 2000$ & Perforate brick & $\begin{array}{l}4 \quad \Phi 12 \\
6 \Phi 12\end{array}$ & Truss \\
\hline $\mathrm{HR}^{* *} \mathrm{~PB} 10$ & $2000 \times 300 \times 1000$ & Perforate brick & $\begin{array}{l}4 \Phi 10 \\
6 \Phi 10\end{array}$ & Truss \\
\hline HRPB12 & $2000 \times 300 \times 1000$ & Perforate brick & $\begin{array}{lll}4 & \Phi & 12 \\
6 & \Phi & 12\end{array}$ & Truss \\
\hline
\end{tabular}

* PB: Perforate Brick; **HR: Horizontal Rectangle. 


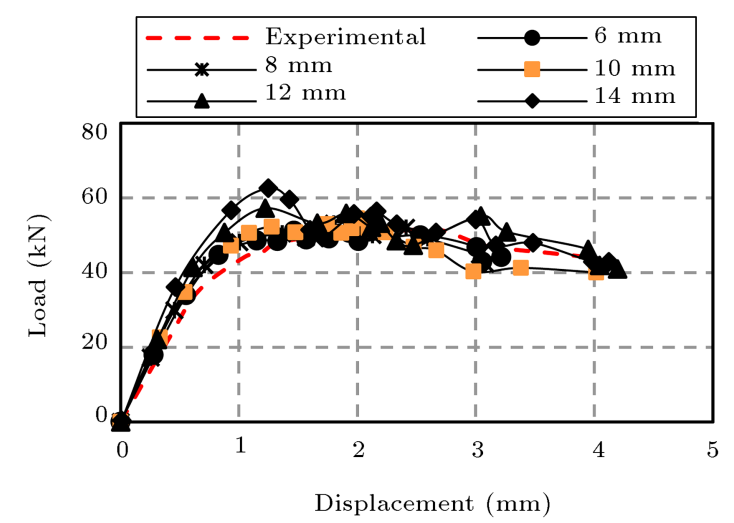

(a)

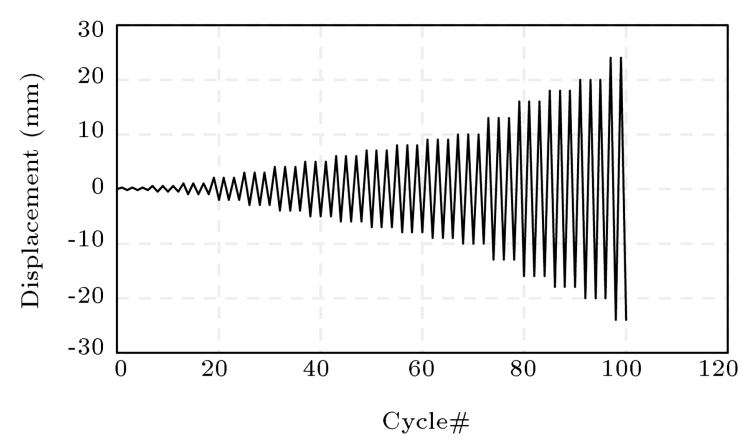

(b)

Figure 6. (a) Effect of mesh size on the system and (b) loading protocol.

the masonry walls. The upper beam was connected to the wall through interface elements modeled with linear behavior and infinite stiffness to simulate the perfect bond between connected elements.

\section{Material model and mechanical property}

The most significant aspect of this section is to introduce the mechanical properties of joints, solid bricks, and perforated bricks with continuous webs and shells that help improve the strength of bricks and the whole wall. Their mean compressive strength in the direction of vertical loads was $9.26 \mathrm{~N} / \mathrm{mm}^{2}$ and in the direction orthogonal to vertical loads, was $13.24 \mathrm{~N} / \mathrm{mm}^{2}$ [20]. Moreover, yielding stress of $F_{y}=500 \mathrm{~N} / \mathrm{mm}^{2}$ was used for steel bars mounted on the reinforced masonry walls. In the micro-modeling approach, distinct materials were used to show the behavior of reinforced masonry walls and, indeed, distinct materials were described as perforated and solid clay bricks, cracks pattern, and unit-mortar interface. Moreover, in this strategy, two-dimensional plan-stress interface element plays an important role [26]. The candidate LS-DYNA materials for masonry walls are soil and foam material model, pseudo tensors' material model, concrete material model, win-frith concrete material model, cap material model NO. 25, NO. 145, and
NO. 159. In addition, LS-DYNA has fully automated contact analysis capability, which makes this software user-friendly for the contact analysis problem [27]. Of note, all parameters used for numerical modeling were obtained from experimental results (see Tables 1-3). Based on Lourenco and rots modeling strategy [28], to take collapse loads and stiffness into account, it is better to model potential cracks in units. Therefore, potential cracks and stiffness were considered through the discrete cracking model $\left(K_{n}=106 \mathrm{~N} / \mathrm{mm}^{3}\right.$ and $K_{s}=106 \mathrm{~N} / \mathrm{mm}^{3}$, respectively) [29].

\section{Parametric analysis}

In this section, the analytical model of reinforced masonry walls is given. To achieve the desired goals, grid-type steel bars were mounted on the cement core between clay bricks and in other parts, they are mounted on hollow bricks. The dimension of walls is $\left(1 \times 1 \mathrm{~m}^{2}, 1 \times 2 \mathrm{~m}^{2}, 2 \times 1 \mathrm{~m}^{2}\right)$ and the size of steel bars is $\Phi 10$ and $\Phi 12$ for walls with different aspect ratios. The figures of position (dimension and reinforcement) are shown in Table 6 .

\subsection{Ductility and energy absorption}

The ratio of maximum inelastic deformation to effective yield deformation is known as ductility [30]. Determining ductility when yield and ultimate deformation occur is the most perplexing and intricate part of the ductility. The displacement ductility is defined as follows:

$$
\mu_{\delta}=\delta_{u} / \delta_{y}
$$

where $\mu_{\delta}$ is displacement ductility, $\delta_{u}$ ultimate displacement at $80 \%$ of the ultimate load, and $\delta_{y}$ yield displacement. The yield force to the initial secant stiffness is defined as yield displacement. In addition, the energy absorbed by each wall is calculated using Matlab simulation in the positive loading direction. Using the trapezoid rule is another calculation as the areas under hysteresis loops. The total dissipated energy is defined through Eq. (2):

$$
E=\sum\left(\delta_{i+1}-\delta_{i}\right)\left(F_{i+1}+F_{i}\right) / 2,
$$

where $F$ is the force and $\delta$ the displacement.

\subsection{Numerical tests results}

Outcomes obtained from reinforced masonry walls are presented in this section. The comparisons of modeled hysteretic cycles, energy absorption, ductility and failure modes are described here. Based on axial loads and reinforcement, there is a correlation between yielded steel bars and crack creation. In fact, Figure 7 shows that the slender walls developed mostly flexural cracks on the upper left corner of the walls, whereas squat 
Table 6. Dimension of reinforced masonry walls, 4 and 6 longitudinal and transversal steel bars.

\begin{tabular}{|c|c|c|c|c|c|}
\hline \multirow[t]{2}{*}{ Specimens } & \multirow{2}{*}{$\begin{array}{l}\text { Dimension of } \\
\text { wall }(\mathrm{mm})\end{array}$} & \multirow{2}{*}{$\begin{array}{l}\text { Type of } \\
\text { bricks }\end{array}$} & \multirow{2}{*}{$\begin{array}{c}\text { Dimension of cement } \\
\text { part }(\mathrm{mm})\end{array}$} & \multicolumn{2}{|c|}{ Reinforcement } \\
\hline & & & & Longitudinal & Transverse \\
\hline \multirow[t]{2}{*}{ SQRM10 } & $1000 \times 100 \times 1000$ & Clay brick & $1000 \times 100 \times 1000$ & $4 \Phi 10$ & $4 \Phi 10$ \\
\hline & & & & $6 \Phi 10$ & $6 \Phi 10$ \\
\hline \multirow[t]{2}{*}{ SQRM12 } & $1000 \times 100 \times 1000$ & Clay brick & $1000 \times 100 \times 1000$ & $4 \Phi 12$ & $4 \Phi 12$ \\
\hline & & & & $6 \Phi 12$ & $6 \Phi 12$ \\
\hline \multirow[t]{2}{*}{ SLRM10 } & $1000 \times 100 \times 2000$ & Clay brick & $1000 \times 100 \times 2000$ & $4 \Phi 10$ & $4 \Phi 10$ \\
\hline & & & & $6 \Phi 10$ & $6 \Phi 10$ \\
\hline \multirow[t]{2}{*}{ SLRM12 } & $1000 \times 100 \times 2000$ & Clay brick & $1000 \times 100 \times 2000$ & $4 \Phi 12$ & $4 \Phi 12$ \\
\hline & & & & $6 \Phi 12$ & $6 \Phi 12$ \\
\hline \multirow[t]{2}{*}{ HRRM10 } & $2000 \times 100 \times 1000$ & Clay brick & $2000 \times 100 \times 1000$ & $4 \Phi 10$ & $4 \Phi 10$ \\
\hline & & & & $6 \Phi 10$ & $6 \Phi 10$ \\
\hline \multirow[t]{2}{*}{ HRRM12 } & $2000 \times 100 \times 1000$ & Clay brick & $2000 \times 100 \times 1000$ & $4 \Phi 12$ & $4 \Phi 12$ \\
\hline & & & & $6 \Phi 12$ & $6 \Phi 12$ \\
\hline \multirow{2}{*}{ SQPB10 } & $1000 \times 300 \times 1000$ & Perforate brick & - & $4 \Phi 10$ & Truss \\
\hline & $1000 \times 300 \times 1000$ & & & $6 \Phi 10$ & 11USs \\
\hline \multirow{2}{*}{ SQPB12 } & $1000 \times 300 \times 1000$ & Perforate brick & _ & $4 \Phi 12$ & Truss \\
\hline & 1000 人 500 人 1000 & & & $6 \Phi 12$ & \\
\hline \multirow{2}{*}{ SLPB10 } & $1000 \times 300 \times 2000$ & Perforate brick & - & $4 \Phi 10$ & Truss \\
\hline & & & & $6 \Phi 10$ & \\
\hline \multirow{2}{*}{ SLPB12 } & $1000 \times 300 \times 2000$ & Perforate brick & - & $4 \Phi 12$ & Trusc \\
\hline & $1000 \times 300 \times 2000$ & & & $6 \Phi 12$ & $110 \mathrm{ss}$ \\
\hline \multirow{2}{*}{ HRPB10 } & $2000 \times 100 \times 1000$ & Perforate brick & _- & $4 \Phi 10$ & Trucs \\
\hline & $2000 \times 100 \times 1000$ & 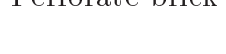 & & $6 \Phi 10$ & $110 \mathrm{ss}$ \\
\hline \multirow{2}{*}{ HRPB12 } & $2000 \times 100 \times 1000$ & Perforate brick & - & $4 \Phi 12$ & $T_{T}$ \\
\hline & $2000 \times 100 \times 1000$ & & - & $6 \Phi 12$ & 1russ \\
\hline
\end{tabular}

walls developed shear cracks on the upper half of the walls, yet without any separation between bricks and mortar. Also, walls with an aspect ratio of $0.5(h / l=$ 0.5 ) represent a rocking failure mode of crack. Furthermore, the energy dissipation, strength and displacement, ductility, and failure modes are of utmost importance in the case of seismic response of a structure.

\subsection{Tests observation}

Load-displacement hysteresis loops analyzed using the modeled walls by LS-DYNA with different types and amounts of reinforcement used in this paper are shown in this section, respectively. First off, the loaddisplacement cycles of the first reinforced group consist of grid-type steel bars mounted on the cement core (see Figure 5(a)) and are presented in the following (see Figure 8). Related comparisons of the mentioned loops in this set were made in terms of maximum strength, displacement capacity, ductility, and crack pattern and energy absorption. Therefore, squat walls with an 

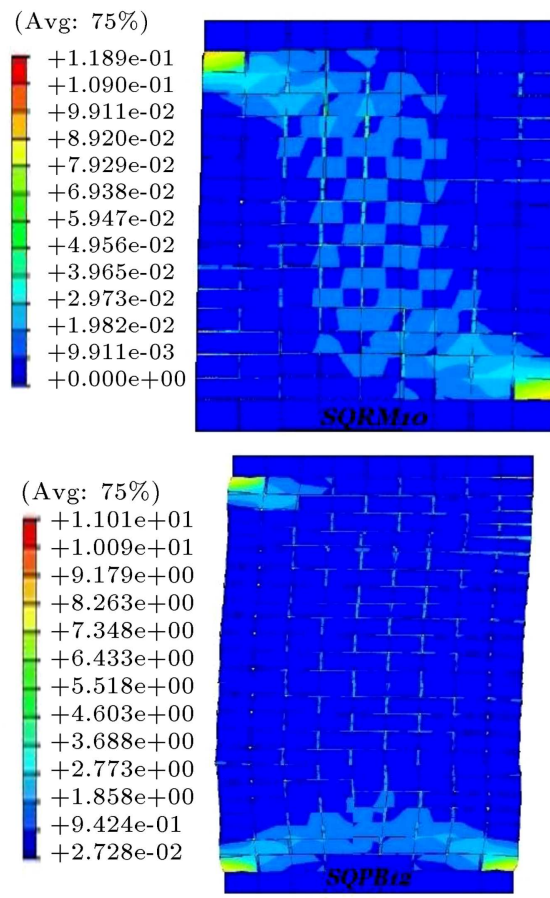

(Avg: 75\%)

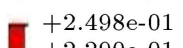

$+2.290 \mathrm{e}-01$

$+2.082 \mathrm{e}-01$

$+1.873 \mathrm{e}-01$

$+1.665 \mathrm{e}-01$

$+1.457 \mathrm{e}-01$

$+1.249 \mathrm{e}-01$

$+1.041 \mathrm{e} 0-1$

$+8.326 \mathrm{e}-02$

$+6.245 \mathrm{e}-02$

$+4.163 \mathrm{e}-02$

$+2.082 \mathrm{e}-02$

$+0.000 \mathrm{e}+00$

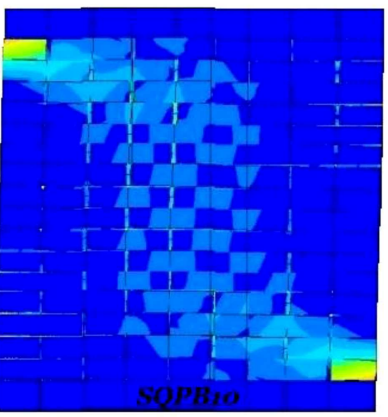

(Avg: $75 \%$ )

$+9.691 \mathrm{e}-02$
$+8.883 \mathrm{e}-02$

$+8.883 \mathrm{e}-02$
$+8.076 \mathrm{e}-02$

$+7.268 \mathrm{e}-02$

$+6.461 \mathrm{e}-02$

$+5.653 \mathrm{e}-02$

$+4.845 \mathrm{e}-02$

$+4.038 \mathrm{e}-02$

$+3.230 \mathrm{e}-02$

$+2.423 \mathrm{e}-02$

$+1.615 \mathrm{e}-02$

$+8.076 \mathrm{e}-03$

$+0.000 \mathrm{e}+00$

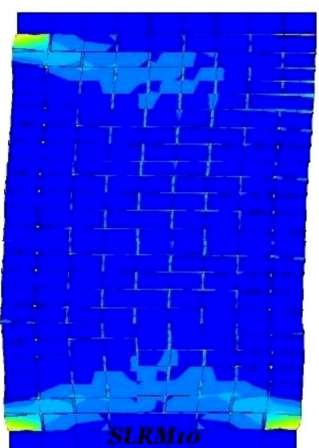

Figure 7. Crack patterns at ultimate displacement and reinforced walls under compressive stresses of $1 \mathrm{~N} / \mathrm{mm}^{2}$.

Table 7. Results of the first group reinforced masonry walls (double-wythe walls).

\begin{tabular}{|c|c|c|c|c|c|c|c|c|}
\hline \multirow{2}{*}{ Specimens } & \multicolumn{2}{|c|}{ Reinforcement } & \multirow{2}{*}{$\begin{array}{c}\text { Elastic shear } \\
\text { force }(\mathrm{kN})\end{array}$} & \multirow{2}{*}{$\begin{array}{c}\text { Maximum } \\
\text { strength } \\
(\mathrm{kN})\end{array}$} & \multirow{2}{*}{$\Delta_{y}(\mathrm{~mm})$} & \multirow{2}{*}{$\Delta_{u}(\mathbf{m m})$} & \multirow{2}{*}{$\mu_{\Delta}$} & \multirow{2}{*}{$\begin{array}{c}\text { Energy } \\
\text { absorption } \\
(\mathrm{kN.mm})\end{array}$} \\
\hline & Vert. & Horiz. & & & & & & \\
\hline \multirow{2}{*}{ SQRM10 } & $4 \Phi 10$ & $4 \Phi 10$ & 94.41 & 208.16 & 3.1 & 11.8 & 3.838 & 1183.804 \\
\hline & $6 \Phi 10$ & $6 \Phi 10$ & 107.5 & 223.80 & 2.20 & 7.91 & 3.590 & 1202.10 \\
\hline \multirow{2}{*}{ SQRM12 } & $4 \Phi 12$ & $4 \Phi 12$ & 101.6 & 218.24 & 3.2 & 12.1 & 3.78 & 1278.430 \\
\hline & $6 \Phi 12$ & $6 \Phi 12$ & 162.60 & 240.57 & 2.5 & 7.8 & 3.12 & 1378.90 \\
\hline \multirow{2}{*}{ SLRM10 } & $4 \Phi 10$ & $4 \Phi 10$ & 28.03 & 76.2 & 5.65 & 19.5 & 3.45 & 904.08 \\
\hline & $6 \Phi 10$ & $6 \Phi 10$ & 56.13 & 80 & 3.42 & 13.5 & 3.68 & 924.421 \\
\hline \multirow{2}{*}{ SLRM12 } & $4 \Phi 12$ & $4 \Phi 12$ & 45.21 & 77.4 & 5.6 & 20.1 & 3.57 & 938.21 \\
\hline & $6 \Phi 12$ & $6 \Phi 12$ & 72.12 & 87.9 & 5.21 & 19.8 & 3.8 & 1042.60 \\
\hline \multirow{2}{*}{ HRRM10 } & $4 \Phi 10$ & $4 \Phi 10$ & 134.35 & 229.70 & 1.2 & 4.5 & 3.75 & 1428.73 \\
\hline & $6 \Phi 10$ & $6 \Phi 10$ & 178.25 & 234.60 & 2.1 & 6.6 & 3.35 & 1518.960 \\
\hline \multirow{2}{*}{ HRRM12 } & $4 \Phi 12$ & $4 \Phi 12$ & 142.20 & 241.12 & 1.7 & 5.2 & 3.47 & 1529.30 \\
\hline & $6 \Phi 12$ & $6 \Phi 12$ & 189.70 & 252.30 & 2.4 & 8.1 & 3.298 & 1577.870 \\
\hline URM & - & - & 101.26 & 152.32 & 2.1 & 5.5 & 2.6 & 1141.007 \\
\hline
\end{tabular}

aspect ratio of $1(h / l=1)$ represent better responses because of an appropriate height to length ratio. Walls with an aspect ratio of $(h / l=0.5)$ show a similar response with a rocking failure mode. In the case of walls with an aspect ratio of $2(h / l=2)$, the whole conditions have improved extensively. The results are given in Table 7 .

In the second group, steel bars of grid type are mounted on hollow bricks and trusses (see Figures 1(a) and $5(\mathrm{~b}))$ as horizontal reinforcements. Figure 9 shows 

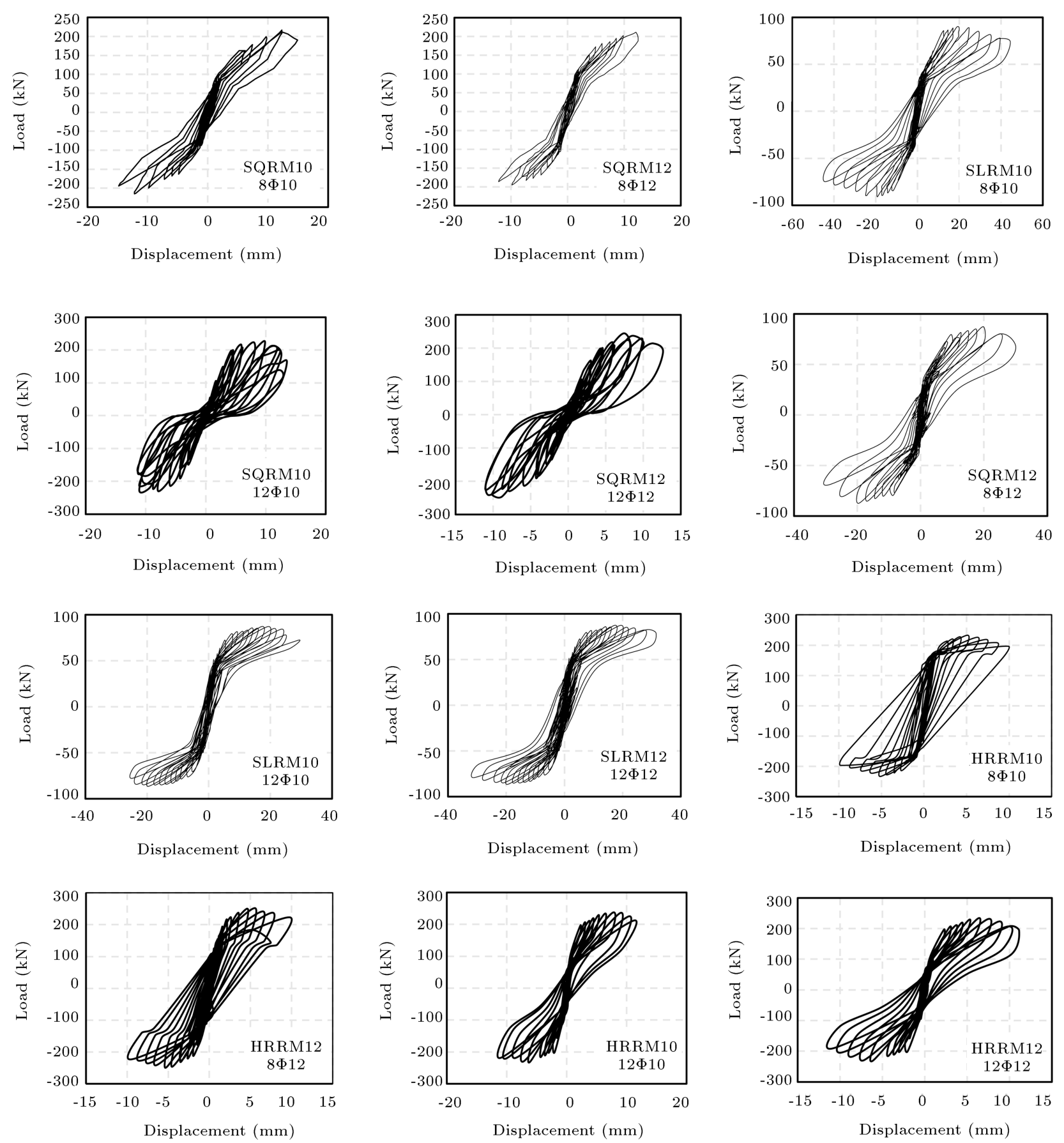

Figure 8. Hysteretic and cyclic shear compression tests. Double-wythe walls tested under $1 \mathrm{~N} / \mathrm{mm}^{2}$ vertical compression.

numerical hysteresis loops as well as the comparison of the relationship between the lateral load and displacement of the wall in the second group. Indeed, the main reason for analyzing this group is to assess the best functionality of reinforced walls in case of a considerable change to the location of steel bars mounted on hollow bricks. Similar to the first group, walls with an aspect ratio of $1(h / l=1)$ showed closer results to the walls with cement core and special truss reinforcement, which led to an increase in the stability and fewer separation of bricks in this group. Results are summarized in Table 8. In what follows, Figure 10 shows the differences between double-wythe and perforated reinforced masonry walls as the values of dissipated energy and ductility.

\subsection{Influence of reinforcement}

\subsubsection{Horizontal reinforcement}

Horizontal reinforcement improved the integrity of bricks and mortar bond drastically against lateral 

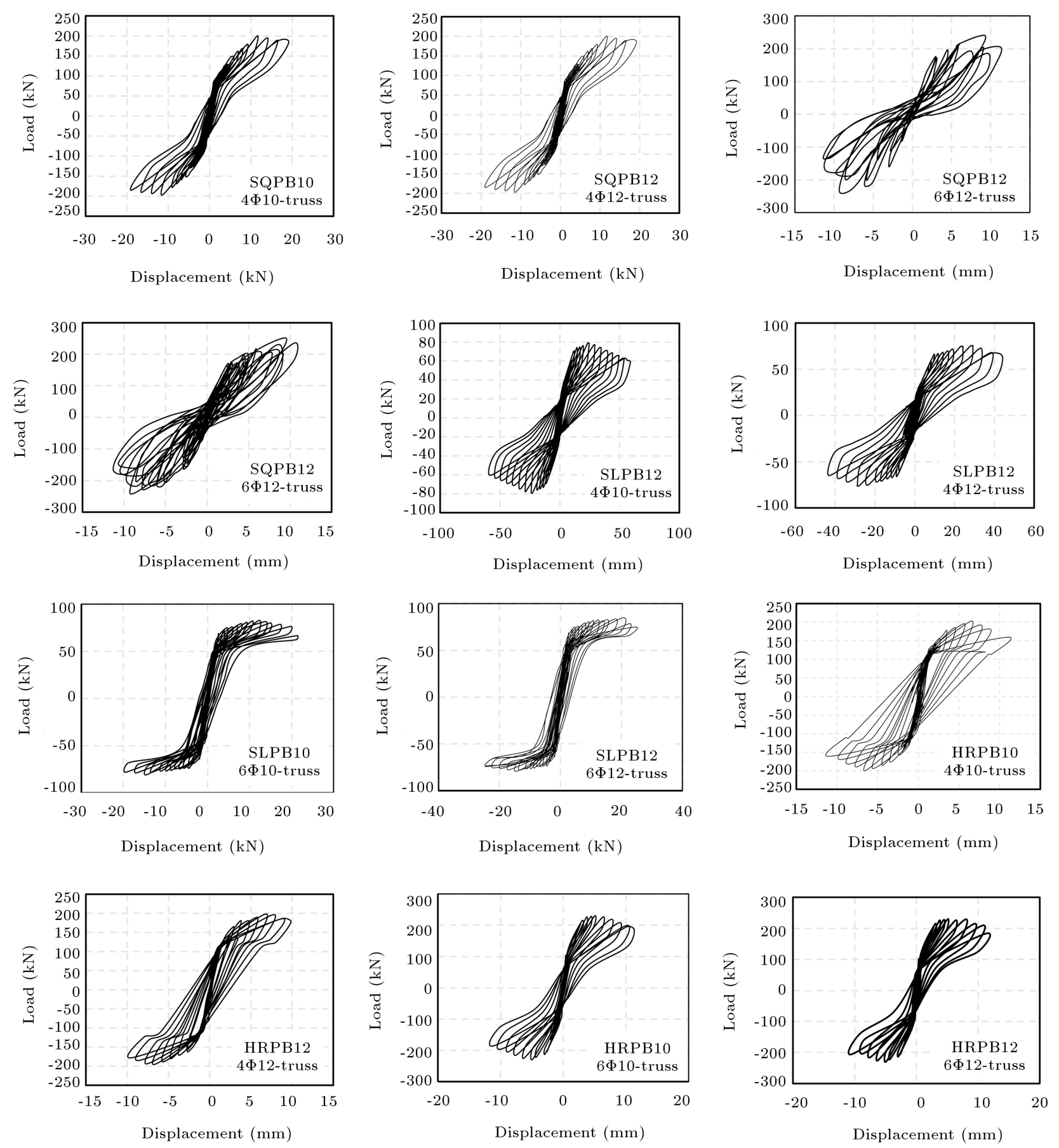

Figure 9. Hysteretic and cyclic shear compression tests. Perforated brick walls tested under $1 \mathrm{~N} / \mathrm{mm}^{2}$ vertical compression.

loads. The most important feature of the horizontal reinforcement is that cracks will stop widening and propagating through the walls against horizontal and vertical loads. Also, this type of reinforcement could have an important effect on slender walls and also on the walls reinforced by truss reinforcement because of the smaller strain of trusses than horizontal steel bars [31]. In general, horizontal reinforcement could contribute greatly to the durability and stability of masonry clay brick walls. Figures 11 and 12 show the influence of horizontal reinforcement on the system, in which with the enhancement of horizontal steel bars, better conditions in terms of carrying capacity, energy absorption, and ductility for slender walls would ensue.

\subsubsection{Vertical reinforcement}

Generally, vertical reinforcement comes to fruition before the attainment of maximum lateral load and 
Table 8. Results of the second group reinforced masonry walls (perforated brick walls).

\begin{tabular}{|c|c|c|c|c|c|c|c|c|}
\hline \multirow[t]{2}{*}{ Specimens } & \multicolumn{2}{|c|}{ Reinforcement } & \multirow{2}{*}{$\begin{array}{c}\text { Elastic shear } \\
\text { force }(k N)\end{array}$} & \multirow{2}{*}{$\begin{array}{l}\text { Maximum } \\
\text { strength } \\
(\mathrm{kN})\end{array}$} & \multirow[t]{2}{*}{$\Delta_{y}(\mathbf{m m})$} & \multirow[t]{2}{*}{$\Delta_{u}(\mathrm{~mm})$} & \multirow[t]{2}{*}{$\mu_{\Delta}$} & \multirow{2}{*}{$\begin{array}{c}\text { Energy } \\
\text { absorption } \\
\text { (kN.mm) }\end{array}$} \\
\hline & Vert. & Horiz. & & & & & & \\
\hline \multirow{2}{*}{ SQPB10 } & $4 \Phi 10$ & \multirow{2}{*}{ Truss } & 81.8 & 201.9 & 3.9 & 15.2 & 3.89 & 1086.437 \\
\hline & $6 \Phi 10$ & & 160.4 & 212.91 & 2.9 & 9.2 & 3.40 & 1210.109 \\
\hline \multirow{2}{*}{ SQPB12 } & $4 \Phi 12$ & \multirow{2}{*}{ Truss } & 96.26 & 205.33 & 3.1 & 11.9 & 3.83 & 1171.007 \\
\hline & $6 \Phi 12$ & & 172.38 & 250.12 & 2.8 & 9.6 & 3.38 & 1298.35 \\
\hline \multirow{2}{*}{ SLPB10 } & $4 \Phi 10$ & \multirow{2}{*}{ Truss } & 28.7 & 76.1 & 5.68 & 22 & 3.87 & 846.403 \\
\hline & $6 \Phi 10$ & & 70.2 & 84.76 & 2.7 & 10.4 & 3.89 & 921.6 \\
\hline \multirow{2}{*}{ SLPB12 } & $4 \Phi 12$ & \multirow{2}{*}{ Truss } & 34.10 & 83.2 & 5.7 & 23 & 3.85 & 893.3 \\
\hline & $6 \Phi 12$ & & 75.23 & 86.54 & 4.1 & 16 & 3.90 & 1001.34 \\
\hline \multirow{2}{*}{ HRPB10 } & $4 \Phi 10$ & \multirow{2}{*}{ Truss } & 163.04 & 200.17 & 2.7 & 6.8 & 3.85 & 1168.74 \\
\hline & $6 \Phi 10$ & & 110.43 & 224.22 & 1.6 & 4.5 & 3.51 & 1211.65 \\
\hline \multirow{2}{*}{ HRPB12 } & $4 \Phi 12$ & \multirow{2}{*}{ Truss } & 165.72 & 205.2 & 2.7 & 6.7 & 3.48 & 1178.9 \\
\hline & $6 \Phi 12$ & & 137.76 & 234.9 & 2.7 & 8.8 & 3.29 & 1237.80 \\
\hline URM & - & - & 101.26 & 152.32 & 2.1 & 5.5 & 2.6 & 1141.007 \\
\hline
\end{tabular}
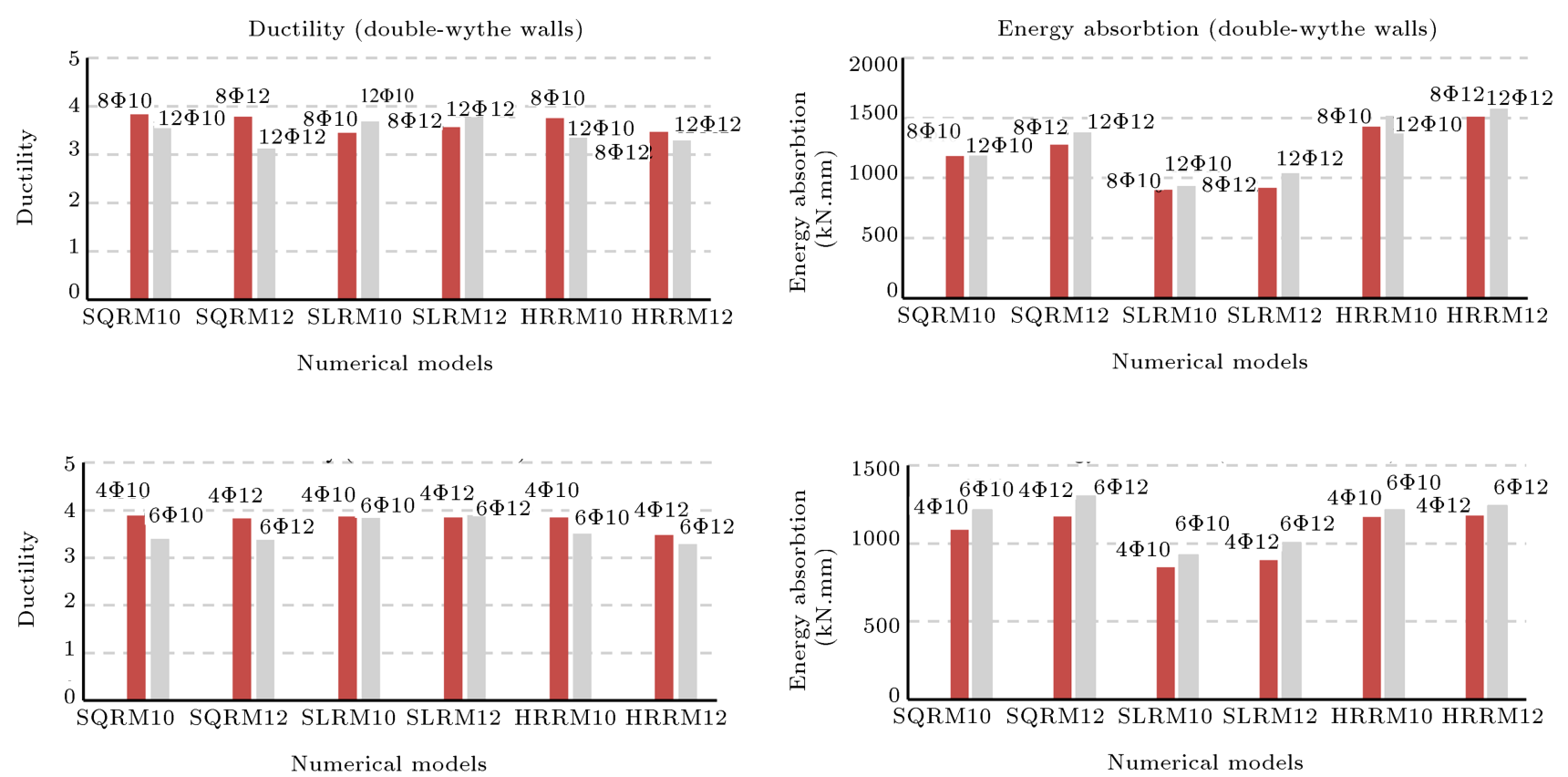

Figure 10. Comparison of double-wythe walls with perforated walls. 

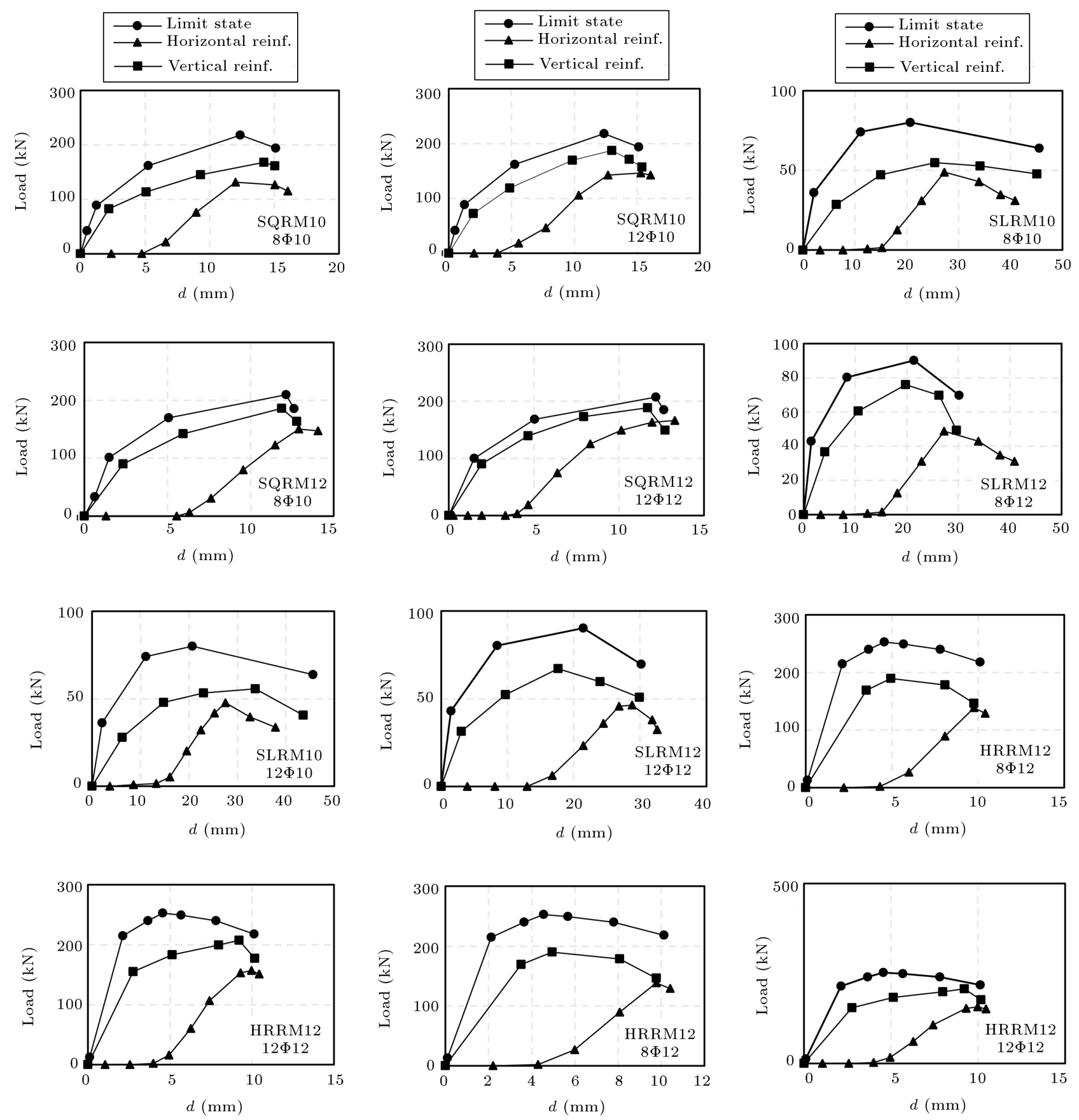

Figure 11. Behavior of vertical and horizontal steel bars in double-wythe walls.

concurrently, the crushing of masonry and buckling of reinforcement occur in the compression zone. Buckling and crushing are both disadvantageous to masonry walls; however, although it is difficult to determine both of them using numerical investigation, vertical reinforcement could contribute greatly to the increased shear strength capacity of masonry walls subjected to compressive and lateral loads (see Figures 11 and 12). However, as implied by the results of slender walls, vertical reinforcement did not help develop the shear capacity of masonry walls. Finally, the effects of reinforcement, whether horizontal or vertical ones, are beneficial for walls with an aspect ratio of $1(h / l=$ 1), mainly because of higher shear strength, lower displacement, and stiffness. In the case of walls with an aspect ratio of $2(h / l=2)$, the displacement capacity of reinforced walls was higher than that of walls with an aspect ratio of 1 . Besides, walls with an aspect ratio of $(h / l=0.5)$ showed a suitable response to the rocking failure crack pattern. That being so, vertical and horizontal reinforcements had positive effect on the performance of slender walls. 

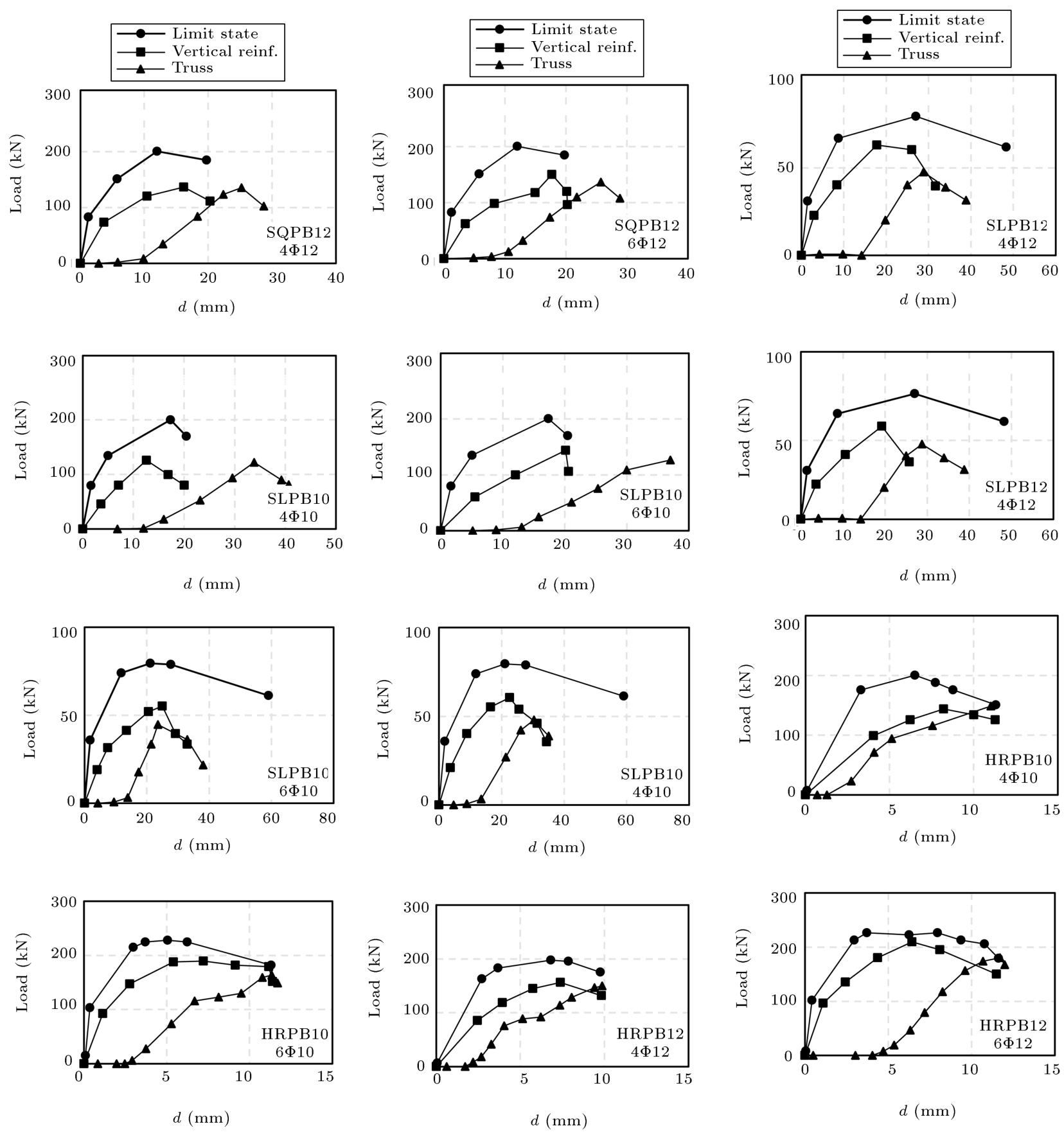

Figure 12. Behavior of vertical and Truss steel bars in squat perforated brick walls.

9.5. Comparison with other reinforced systems This section shows a comparison between various reinforced systems proposed by different authors and the current method. As shown in Figure 13, doublewythe and Perforated bricks reinforced walls in this system are in good agreement with other reinforced systems. In walls with aspect ratios of 1 and 2, Zhang et al. [32], Shabdin et al. [33], Sandoval et al. [34], and Farooq et al. [35] showed a lower carrying capacity and displacement than double-wythe and perforated reinforced walls. Slender walls with an aspect ratio of $(h / l=2)$ had a better condition than this system, perhaps due to the location of steel bars in the wall. Also, walls with an aspect ratio of 0.5 showed better results than this system. As Figure 13 shows, $w 7$ shows a better condition in case of maximum strength and displacement; however, $w 6$ represents a close behavior compared to other reinforced walls. That being so, there is no doubt that using steel bars or FRP materials improves the seismic behavior of un-reinforced walls. Moreover, more research needs to be done to develop the performance of masonry walls because various 

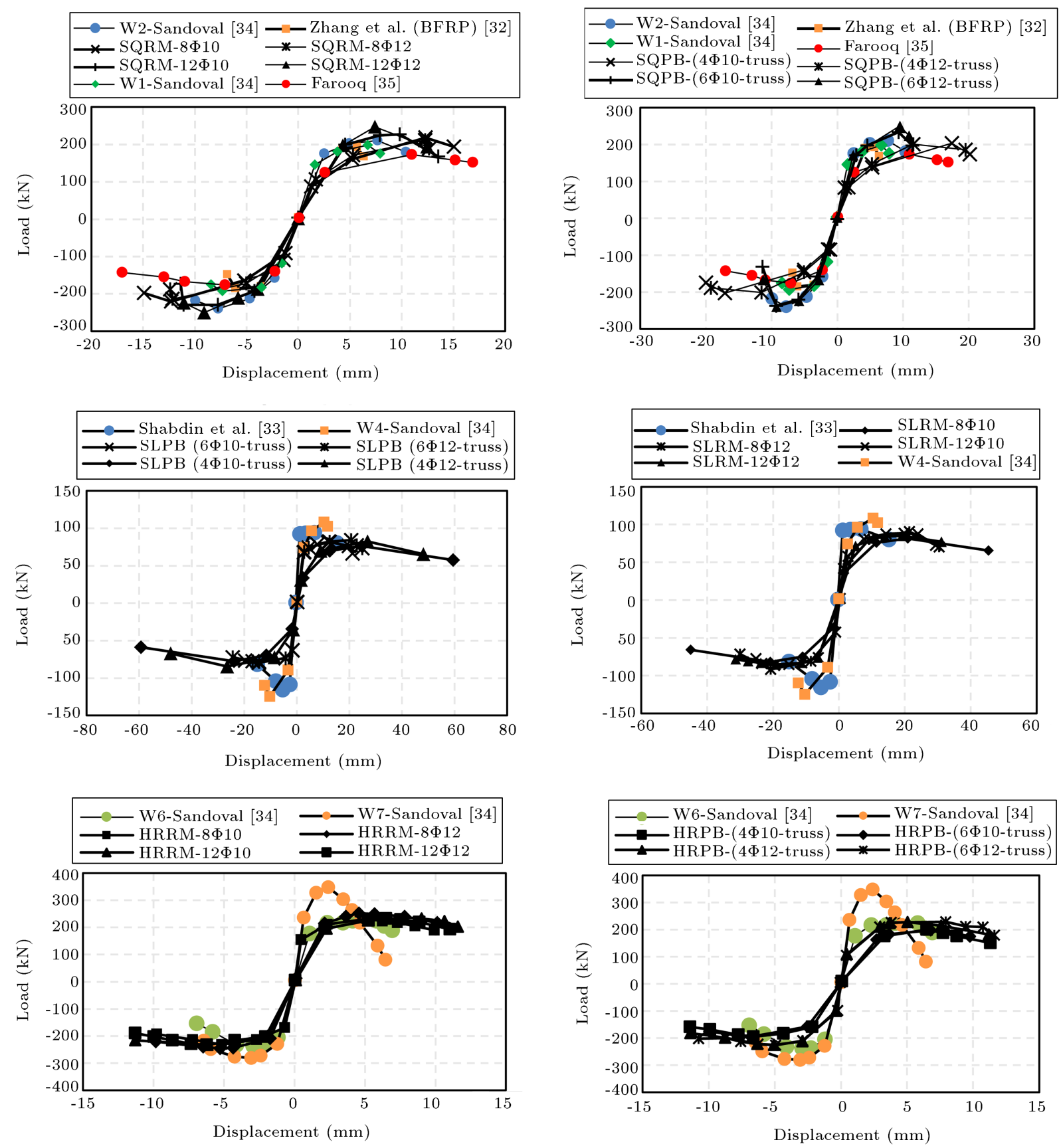

Figure 13. Comparison of double-wythe and perforated brick walls with different reinforced systems.

parameters like the location of steel bars, reinforcement ratio, or dimension of walls play a crucial role in analyzing and designing reinforced masonry walls.

\section{Wall design formula}

Many researchers have conducted an extensive test program on normal and high strength reinforced masonry walls with different aspect ratios $\left(h_{w} / t_{w}\right)$. These studies have concluded that a reliable design formula would be needed. The proportion of maximum strength to reinforcement ratio led to a linear equation in which the $\left(h_{w} / t_{w}\right)$ ratio for reinforced masonry walls was kept constant in each diagram and maximum resistance varied as the reinforcement ratio changed (see Figure 14). These figures and equations facilitate the calculation of carrying capacity according to the ratio of $\left(h_{w} / t_{w}\right)$, where $h_{w}=$ height of wall $(\mathrm{mm})$ and $t_{w}=$ thickness of the wall $(\mathrm{mm})$. By using the test results and published data of double-wythe reinforced walls in this study, the formula designed to calculate carrying capacity takes the following form:

$$
F_{d w}=\alpha \rho+\eta,
$$



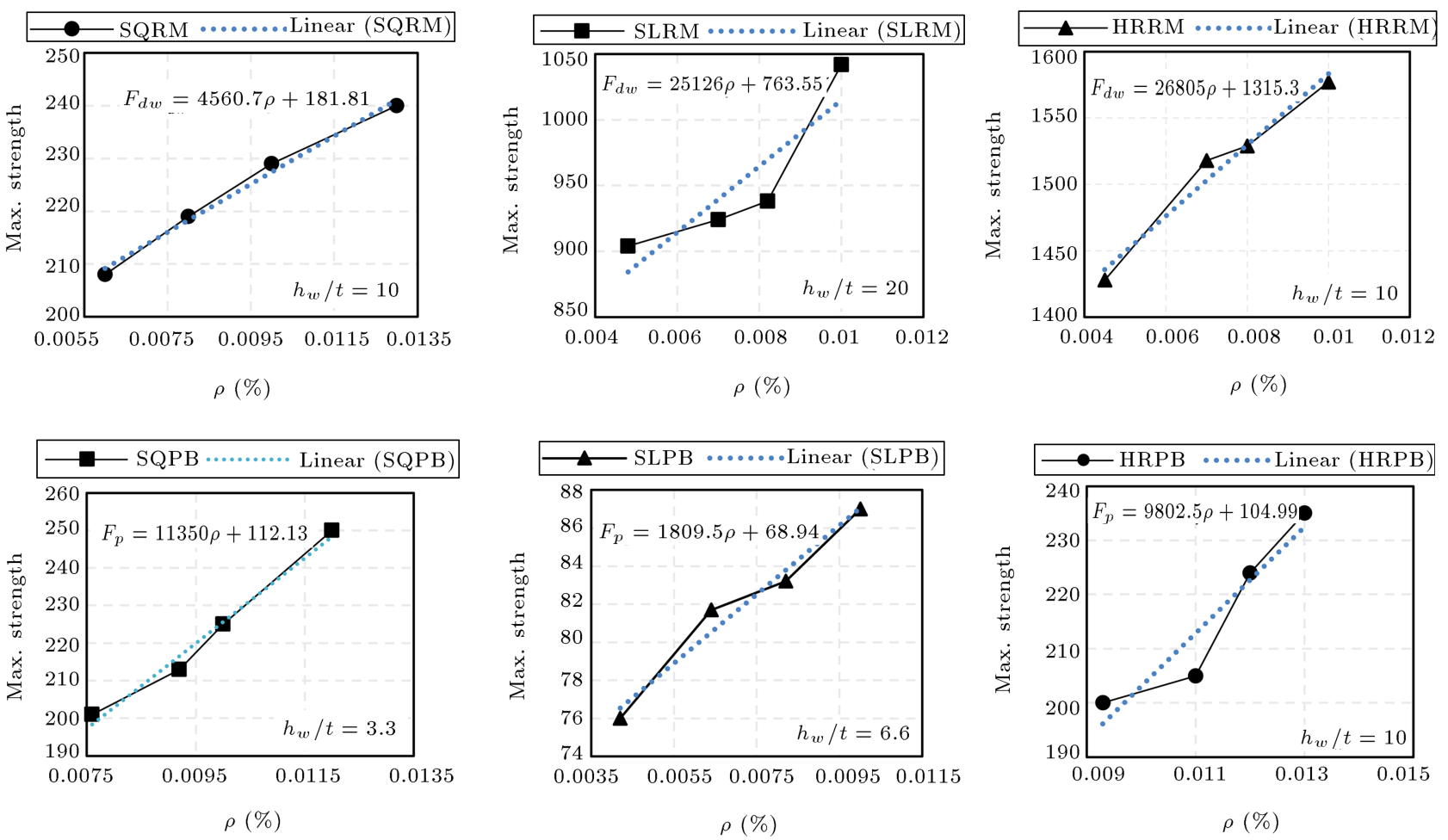

Figure 14. Detailed design formulas used to calculate the carrying capacity.

where $F_{d w}$ is the maximum load per unit length of double-wythe walls (kN.mm), $\alpha$ and $\eta$ are constant for each diagram (will determine based on Figure 14), and $\rho$ is the reinforcement ratio (\%).

Regarding Perforated brick walls, the formula used to calculate carrying capacity is similar to doublewythe walls, where constant parameters vary, as shown in Figure 14. The design formula takes the following form:

$$
F_{p}=\beta \rho+\psi,
$$

where $F_{p}$ is the maximum load per unit length of perforated brick walls (kN.mm), $\beta$ and $\psi$ are constant for each diagram (determine based on Figure 14), and $\rho$ is the reinforcement ratio (\%).

\section{Conclusion}

This study proposed an innovative system using gridtype steel bars mounted on the cement core and perforated bricks as the second group. To this end, the methodology of research was applied based on the numerical simulation done using appropriate LSDYNA (FEM) software (discrete modeling) and the primary stage was devoted to the validation of numerical analysis based on recent experimental works. The behavior of reinforced masonry walls in terms of maximum strength, failure modes, energy absorption, ductility, loads, and displacement was studied in order to assess their seismic performance, which was the main objective of this work. In this paper, four models were built by solid clay brick and four others by special perforated bricks. Steel bars mounted on the wall are of the following two types:

1. Steel bars of grid type mounted on the cement hollow bricks;

2. Steel bars of grid type mounted on the cement core between clay bricks.

Steel bars mounted on the cement core between clay brick exhibited better performance in case of shear resistance and displacement. In addition, brick walls were enhanced substantially following the addition of horizontal bars and perpendicular to the walls. The major weakness of brick walls is their low shear strength. Reinforced brick walls and horizontal bars could prevent any crack opening. Results demonstrated that walls with aspect ratios of 1 and 0.5 had higher maximum resistance than those with an aspect ratio of 2. Also, the presence of horizontal and vertical steel bars provided an opportunity for walls to prevent cracks from opening. Indeed, reinforcement not only developed the integrity and durability of brick walls noticeably, but also ensured lower dissipated energy and lower displacement. In general, squat walls had better performances in terms of ductility, energy absorption, and crack patterns. Furthermore, truss horizontal reinforcement improved the seismic behavior of masonry walls significantly because of lower strains than those horizontal steel bars mounted on the cement core. 


\section{References}

1. Tomaževiè, M., Earthquake-Resistant Design of Masonry Buildings, London: Imperial College Press (1999).

2. Corradi, M., Di Schino, A., Borri, A., and Rufini, R. "A review of the stainless steel for masonry repair and reinforcement", Construction and Building Materials, 181, pp. 335-346 (2018). DOI: /10.1016/j.conbuildmat.2018.06.034

3. Babatunde, S.A. "Review of strengthening techniques for masonry using fiber reinforced polymers", Journal of Composite Structures, 161, pp. 246-255 (2016). DOI: /10.1016/j.compstruct.2016.10.132

4. Basili, M., Marcari, G., and Vestroni, F. "Nonlinear analysis of masonry panels strengthened with textile reinforced mortar", Eng. Struct., 113, pp. 245-258 (2015). DOI: /10.1016/j.engstruct.2015.12.021

5. Zhou, Q., Zhu, F., Yang, X., et al. "Shear capacity estimation of fully grouted reinforced concrete masonry walls using neural network and adaptive neurofuzzy inference system models", Construction and Building Materials, 153, pp. 937-947 (2017). DOI: /10.1016/j.conbuildmat.2017.07.171

6. Basili, M. "Numerical modeling of slender masonry walls with FRP under cyclic loading", ASCE Journal, 176, pp. 125-138 (2015).

7. Shermi, C. and Dubey, R.N. "In-plane behaviour of masonry panel strengthened with welded wire mesh and mortar", Construction and Building Materials, 178, pp. 195-203 (2018). DOI: /10.1016/j.conbuildmat.2018.04.081

8. Dehghani, M., Najafgholipour, M., Kamrava, A., and Khajepour, M. "Application of ordinary fiberreinforced concrete layer for in-plane retrofitting of unreinforced masonry walls: Test and Modeling", Scientia Iranica, 26(3), PP. 1089-1103 (2019). DOI: $10.24200 /$ sci.2018.20164

9. Mohebbi, M. and Joghataie, A. "Optimal TMDS for improving the seismic performance of historical building", Scientia Iranica, 23(1), pp. 79-90 (2016).

10. Messali, F., Metelli, G., and Plizzari, G. "Experimental results on the retrofitting of hollow bricks masonry walls with reinforced high performance mortar coatings", Construction and Building Materials, 141, pp. 619-630 (2017).

11. Minaie, E., Mota, M., Moon, F.L., and Hamid, A.A. "In-plane behavior of partially grouted reinforced concrete masonry shear walls", J Struct. Eng., 71, pp. 724-738 (2010).

12. Haach, V.G., Vasconcelos, G., and Lourenco, P.B. "Experimental analysis of reinforced concrete block masonry walls subjected to in-plane cyclic loading", J Struct. Eng., 136(4), pp. 452-62 (2010).
13. Zilch, K., Schermer, D., and Scheufler, W. "Behavior of reinforced masonry walls made of hollow clay units with concrete infill under combined loading", In: Proc. 14th International Brick and Block Masonry Conference (CD-ROM) (2008).

14. Da Porto, F., Mosele, F., and Modena, C. "Experimental testing of tall reinforced masonry walls under out-of-plane actions", Construction \& Building Materials, 24(12), pp. 2559-2571 (2010). DOI: $10.1016 /$ j.conbuildmat.2010.05.020

15. Da Porto, F., Mosele, F., and Modena, C. "Cyclic out-of-plane behavior of tall reinforced masonry walls under P- $\Delta$ effects", Eng. Struct., 33(2), pp. 287-297 (2010). DOI: $10.1016 /$ j.engstruct.2010.10.004

16. Shing, P.B., Schuller, M., and Hoskere, V.S. "In-plane resistance of reinforced masonry shear walls", J Struct. Eng., 116(3), pp. 619-40 (1990).

17. Lourenco, P.B., Rots, J.G., and Blaauwendraad, J.J. "Continuum model for masonry: parameter estimation and validation", J Struct. Eng., 124(6), pp. 642-52 (1998).

18. Haach, V.G., Vasconcelos, G., and Lourenco, P.B. "Parametric study of masonry walls subjected to in-plane loading through numerical modeling", Eng. Struct., 3(4), pp. 1377-89 (2011).

19. DISwall, Developing Innovative Systems for Reinforced Masonry Walls, COOP-CT-2005-018120 (2008).

20. Da Porto, F., Mosele, F., and Modena, C. "Compressive behavior of a new reinforced masonry system", Materials and Structures, 44, pp. 565-581 (2010). DOI: $10.1617 / \mathrm{s} 11527-010-9649-\mathrm{x}$

21. Da Porto, F., Guidi, G., Garbin, E., and Modena, C. "In-plane behavior of clay masonry walls: Experimental testing and finite-element modeling", Journal of Structural Engineering, 136(11), pp. 1379-1392 (2012). DOI: 10.1061/_asce_st.1943-541x.0000236

22. Tomaževiè, M., Lutman, M., and Bosiljkov, V. "Robustness of hollow clay masonry units and seismic behavior of masonry walls", Construction and Building Materials, 20(10), pp. 1028-39 (2006), DOI: 10.1016/j.conbuildmat.2005.05.001

23. Lourenco, P.B. "Computational method for masonry structure", Ph.D Dissertation, Delft University of Technology (1996).

24. Eta/FEMB-PC (Finite Element Model Builder), Version 28, USER'S MANUAL, a pre and post-processor for use with LS-DYNA software (2001).

25. Tomaževič, M. and Lutman, M. "Seismic behavior of masonry walls: modeling of hysteretic rules", J Struct Eng., 122(9), pp. 1048-1054 (1996). 
26. Lourenco, P.B., Rots, J.G., and Blaauwendraad, J. "Continuum model for masonry: parameter estimation and validation", J Struc Eng., 124(6), pp. 642-52 (1998).

27. Bala, S., Tie-Break Contacts in LS-DYNA, Live more Software, USA (2007).

28. Lourenco, P.B. and Rots, J.G. "Multisurface interface model for analysis of masonry structures", J Eng. Mech, 123(7), pp. 660-668 (1997).

29. Lourenco, P.B. "Computational method for masonry structures", Ph.D. Dissertation, Delft University of Technology (1996).

30. Priestley, M.J.N., Calvi, G.M., and Kowalsky, M.J., Displacement-Based Seismic Design of Structures, Pavia, Italy: IUSS Press (2007).

31. Tomaževiè, M. and Zarnic, R. "The behavior of horizontally reinforced masonry walls subjected to cyclic lateral in-plane load reversals", In: Proc. 8th European Conf. of Earthquake Engineering (1984).

32. Zhang, S., Yang, D., Sheng, Y., et al. "Numerical modeling of FRP-reinforced masonry walls under inplane seismic loading", Construction and Building Materials, 134, pp. 649-663 (2017).

33. Shabdin, M., Khajeh Ahmad Attari, N., and Zargaran M. "Experimental study on seismic behavior of UnReinforced Masonry (URM) brick walls strengthened with shotcrete", Springer, J. of Earthquake Eng, 340(18), pp. 123-131 (2018).

34. Sandoval, C., Calderon, S., and Almazan, J.L. "Experimental cyclic response assessment of partially grouted reinforced clay brick masonry walls", Springer, J. of Earthquake Eng, 308(18), pp. 587-596 (2018).
35. Farooq, S.H., Shahid, I., and Ilyas, M. "Seismic performance of masonry strengthened with steel strips", KSCE Journal of Civil Engineering, 18(7), pp. 21702180 (2014).

\section{Biographies}

Bahman Shakarami received his BS degree in Civil Engineering from Azad University and an MS degree in Structural Engineering from Amirkabir University of Technology, Tehran, Iran. His research interests are in the areas of reinforced masonry and concrete, composite materials, and modeling and rehabilitation of structural members.

Mohammad Zaman Kabir is a Professor at and the Chair of Civil and Environmental Engineering Department at Amirkabir University of Technology, Tehran, Iran. He received his BS and MS degrees from Amirkabir University of Technology and his $\mathrm{PhD}$ degree from Waterloo University in Canada. His research interests include structural masonry, structural stability, and structural analysis using FEM, experimental methods in structural engineering, composite structures (FRP), structural optimization, damage detection, and rehabilitation of structures.

Razieh Sistani Nezhad received her MS degree from Sharif University of Technology and his PhD degree in structural engineering from Amirkabir University of Technology, Tehran, Iran. Her research interests include masonry structures, structural stability, and structural analysis using FEM, experimental methods in structural engineering, composite structures, and modeling and rehabilitation of structural members using FRP materials. 